\title{
ANALISIS IMPLEMENTASI PENERAPAN SOP FUNDING DAN FINANCING DALAM MENCIPTAKAN AKUNTABILITAS PADA BMT NATIJATUL UMAT
}

\author{
Mira Rahmi $\oplus^{1)}$ dan Lili Puspita Sari $\oplus^{2)}$ \\ ${ }^{1,2}$ Ekonomi Syariah, Fakultas Ekonomi dan Bisnis, Universitas Pembangunan Nasional Veteran Jakarta \\ 1,2 Jalan RS Fatmawati No.1, Jakarta Selatan, 12450 \\ E-mail: mirarahmi@upnvj.ac.id ${ }^{1)}$, lilipuspitasari@upnvj.ac.id ${ }^{2)}$
}

\begin{abstract}
ABSTRAK
Penelitian ini bertujuan untuk mengetahui penerapan sistem informasi akuntansi (SIA) melalui implementasi prosedur funding (penghimpunan dana) dan implementasi prosedur financing (pembiayaan) pada BMT Natijatul Umat (BMT NJU), dan apakah penerapan SIA tersebut dapat menciptakan akuntabilitas. Penelitian ini merupakan penelitian kualitatif deskriptif dengan menggunakan data sekunder. Akuntabilitas dinilai melalui akuntabilitas proses dan akuntabilitas koperasi yaitu aspek keuangan berdasarkan Peraturan Pemerintah Koperasi dan Usaha Kecil Menengah (Permen KUKM). Akuntabilitas proses terkait dengan apakah prosedur yang telah digunakan dalam melaksanakan tugas sudah cukup baik dalam hal kecukupan sistem informasi akuntansi, sistem informasi manajemen dan prosedur administrasi. Hasilnya menunjukkan bahwa akuntabilitas BMT NJU dapat tercipta melalui akuntabilitas proses, yaitu penerapan SIA berupa implementasi prosedur funding dan financing yang memadai. Melalui akuntabilitas koperasi yaitu aspek keuangan berupa ketersediaan sistem informasi dan transparansi pengelolaan sistem akuntansi oleh BMT NJU. Penelitian ini dapat dijadikan sebagai informasi dalam meningkatkan kinerja BMT NJU. Keterbatasan dalam penelitian ini yaitu penerapan SIA dalam menciptakan akuntabilitas, baru diukur melalui implementasi penerapan prosedur funding dan financing yaitu aspek akuntabilitas proses serta aspek keuangan yaitu ketersediaan sistem informasi dan transparansi. Akuntabilitas itu sendiri dapat tercipta dari berbagai aspek akuntabilitas lain, yaitu akuntabilitas kejujuran dan akuntabilitas hukum, akuntabilitas program, dan akuntabilitas kebijakan.
\end{abstract}

Kata kunci: Akuntabilitas, BMT, Funding, Financing, SIA

\section{PENDAHULUAN}

Peranan Lembaga Keuangan Mikro Syariah (LKMS) bagi perkembangan perekonomian, terutama bagi pemberdayaan Usaha Kecil dan Menengah (UKM) sangat penting. Keberlangsungan pertumbuhan usaha kecil dan menegah dapat terbantu dengan adanya LKMS, yaitu dari sisi permodalan. Selain mempunyai peran sebagai solusi permodalan bagi UKM, LKMS juga memiliki fungsi lain yaitu menangani kegiatan sosial. BMT Natijatul Umat (BMT NJU) yang berlokasi di Kecamatan Babadan Ponorogo, merupakan salah satu bentuk LKMS. Peran Baitul Maal wat Tamwil (BMT) di masa pandemi virus Corona (Covid19) menjadi penting terutama dalam meningkatkan dan menguatkan fungsi pengelolaan ZISWaf-nya kepada anggota atau nasabah yang terdampak pandemi Covid19 oleh karena itu diperlukan kinerja yang baik agar BMT NJU dapat melaksanakan fungsi tersebut.

Kinerja BMT NJU, Menurut (Khoiriyah, 2017) menunjukkan tingkat Risk Profile (Profil Risiko) BMT NJU pada tahun 2012 sampai dengan tahun 2014 masuk kedalam kategori tidak memadai. Baru kemudian di tahun 2015 meningkat menjadi kategori memadai. Risk profile dalam aktivitas operasional perbankan menunjukkan kualitas penerapan manajemen risiko yang terdiri atas 7 (tujuh) jenis risiko antara lain yaitu risiko operasional dan risiko kepatuhan. Oleh karena itu diperlukan upaya untuk mempertahankan citra positif tersebut, agar kinerja BMT NJU dapat terjaga. Implementasi Sistem Informasi Akuntansi (SIA) dapat menciptakan kinerja suatu lembaga secara maksimal, karena adanya proses kerja yang lebih efektif dan efisien. Proses kerja ini dapat tercermin dari implementasi penerapan prosedur funding dan prosedur financing, dan bagi suatu lembaga itu akan memberikan dampak jangka panjang yang dapat meningkatkan akuntabilitas nya.

Pondok Pesantren Sabilurrosyad mengindikasikan perlunya perancangan SIA dalam menciptakan administrasi keuangan yang tertib sehingga dapat di pertanggung jawabkan, serta adanya pemisahan tugas sesuai fungsinya pada struktur organisasi (Sulistiani, 2019). Pada Bank Islam di Yordania, umumnya menunjukkan bahwa Sistem Informasi Akuntansi atau Accounting Information System (AIS) membantu dalam memberikan informasi yang tepat mengenai substansi yang tersedia secara efektif (Alrabei, 2017).

Sebaliknya pelaksanaan SIA yang buruk akan memberikan dampak negatif, menurut (Wijayanti, 2010) pembiayaan bermasalah muncul di BMT Bondho Tumoto Gunungpati Semarang karena fungsi yang terkait, dokumen dan catatan akuntansi yang 
digunakan, bagan alir sistem akuntansi pembiayaan, laporan yang dihasilkan, serta unsur-unsur pengendalian intern tidak diimplementasikan dengan baik. (Mubarok and Utami, 2016) menyatakan bahwa lembaga keuangan mikro syariah Baitul Maal Wa Tamwiil (BMT) di Tegal, secara umum menerapkan sistem informasi akuntansi yang dinilai dari 16 unsur, dengan unsur tertinggi adalah unsur pencatatan modal. Namun unsur penyusunan analisis laporan keuangan masih jarang dilaksanakan, padahal hal tersebut erat kaitannya sebagai bentuk transparansi untuk menilai kinerja BMT.

Selain pentingnya ketersediaan unsur SIA yang memadai, diperlukan juga adanya pengawasan terhadap pelaksanaannya. Seperti yang terjadi pada pelaksanaan pembiayaan mudharabah tanpa agunan di KSPPS Amanah Usaha Mulia (AULIA) Magelang, karena kurangnya pengawasan terhadap prosedur pembiayaan yang dilakukan oleh account officer, sehingga mengakibatkan kesalahan dalam proses analisis pembiayaan (Nuraeni, 2019). Hasil penelitian (Noor, 2018) pada Koperasi Jasa Keuangan Syariah Baitul Maal Wattamwil Binaan Dinas Koperasi (KJKS BMT/KSPPS) dan UKM Kota Padang menunjukkan bahwa penerapan akuntabilitas berdasarkan Permen KUKM Nomor 20 Tahun 2015 tentang penerapan pelaksanaan akuntabilitas. Ditemukan kendala yang menjadi penghambat adalah kurangnya pemahaman oleh pengawas, pendamping, pengelola, pengurus, dan anggota koperasi itu sendiri terhadap kinerja dan program yang dijalankan, serta kepatuhan terhadap pelaksanaan tugas dengan maksimal terutama mengenai syariah Islam.

Penerapan SIA pembiayaan murabahah dalam menunjang efektivitas pengendalian internal pada PT Bank BNI Syariah kantor cabang Cirebon diukur melalui penilaian Non Performing Financing (NPF) (Wartoyo and Meutia, 2016). BMT Al-Madinah yang berlokasi di Surakarta menerapkan sistem informasi pelaksanaan fungsi keuangan atau akuntansi dengan prinsip akuntabilitas dan transparansi melalui kepatuhan terhadap aspek akuntabilitas proses melalui job description serta reward and punishment (Usnan, 2019). Dapat dilihat bahwa implementasi SIA pada perbankan adalah sebagai sistem pengawasan, kontrol serta evaluasi terhadap pembiayaan yang disalurkan agar lebih efektif dan terkendali. Sedangkan pada Organisasi Pengelola Zakat (OPZ) menurut (Rahman, 2015) penerapan SIA serta sumber daya manusia yang baik akan dapat menciptakan transparansi dan akuntabilitas, yang ditunjukkan dengan laporan keuangan Zakat, Infak, Sedekah (ZIS) yang dibuat oleh OPZ setiap periode serta dipublikasikan kepada masyarakat.

Fungsi utama SIA yaitu mengubah sekelompok data menjadi informasi keuangan untuk perusahaan, sehingga prosedur transaksi merupakan syarat penting agar SIA dapat berjalan dengan baik. Terdapat tiga tahap prosedur pembiayaan murabahah di BMT UMY, yaitu: (1) pemohon memenuhi persyaratan, (2) bagian pembiayaan mengumpulkan berkas permohonan pengajuan pembiayaan, dan (3) tim surveyor melakukan analis (Hanjani and Ari Haryati, 2018). Sedangkan pada BMT Batik Mataram prosedur pembiayaan musyarakah dimulai dari permohonan, pemenuhan persyaratan, pemeriksaan kelengkapan, analisis, penginputan data, pembuatan akad, pemeriksaan akad, penyerahan jaminan, baru kemudian pencairan pembiayaan ( Vitasari, 2018).

Dapat dilihat bahwa implementasi Sistem Informasi Akuntansi (SIA) yang baik dan benar dapat menunjang efektivitas pengendalian internal dan mewujudkan terciptanya akuntabilitas. Kepercayaan (trust) masyarakat dapat tercipta melalui akuntabilitas, yang akan berdampak terhadap legitimasi suatu lembaga, baik terhadap lembaga profit maupun lembaga nonprofit, tidak terkecuali bagi BMT NJU. Penelitian ini bertujuan untuk mengetahui penerapan Sistem Informasi Akuntansi (SIA) melalui implementasi prosedur funding (penghimpunan dana) dan implementasi prosedur financing (pembiayaan) pada BMT Natijatul Umat (BMT NJU) dalam menciptakan akuntabilitas.

\section{RUANG LINGKUP}

Pengukuran akuntabilitas atas implementasi SIA dapat dilihat dari Non Performing Financing (NPF) (Wartoyo and Meutia, 2016), kepatuhan terhadap aspek akuntabilitas proses (Usnan, 2019), transparansi melalui publikasi laporan keuangan Zakat, Infak, Sedekah (ZIS) (Rahman, 2015), pelaksanaan prosedur pembiayaan (Hanjani and Ari Haryati, 2018) dan ( Vitasari, 2018), serta berdasarkan Permen KUKM Nomor 20 Tahun 2015 (Noor, 2018).

Batasan pada penelitian ini adalah analisis penerapan SIA yang dilakukan yaitu melalui implementasi penerapan prosedur funding dan prosedur financing pada BMT Natijatul Umat. Tujuannya adalah untuk mengetahui apakah penerapan tersebut dapat menciptakan akuntabilitas bagi BMT NJU. Akuntabilitas tersebut diukur berdasarkan akuntabilitas proses terkait prosedur yang digunakan yaitu kecukupan sistem informasi akuntansi, sistem informasi manajemen dan prosedur administrasi. Dan berdasarkan Permen KUKM Nomor 20 Tahun 2015 yaitu ketersediaan sistem informasi, dan transparansi pengelolaan sistem akuntansi.

\section{BAHAN DAN METODE}

Lembaga Keuangan Mikro Syariah (LKMS) adalah lembaga berbadan hukum yang kegiatan operasional usahanya menggunakan asas simpan pinjam dan bagi hasil yang berlandaskan prinsip-prinsip syariah. Lembaga yang termasuk kedalam LKMS adalah Koperasi Jasa Keuangan Syariah (KJKS) dan Baitul Mal wa Tamwil (BMT). Definisi BMT menurut 
operasional PINBUK (Pusat Inkubasi Bisnis Usaha Kecil) adalah balai usaha mandiri terpadu yang isinya berdasarkan bayt al-mal wa al-tamwil dalam mengembangkan usaha produktif serta investasi untuk meningkatkan kualitas ekonomi pengusaha kecil. Selain itu BMT dalam kegiatan usahanya juga dapat menerima titipan Zakat, Infak, Sedekah (ZIS) serta menyalurkan sesuai dengan peraturan dan amanatnya. (Andri Soemitra, 2017)

Sistem informasi akuntansi (SIA) merupakan jaringan dari seluruh prosedur, formulir-formulir, catatan-catatan, dan alat-alat yang digunakan untuk mengolah data keuangan menjadi suatu laporan yang dapat digunakan oleh pihak manajemen dalam mengendalikan kegiatan usahanya. Prosedur adalah serangkai kegiatan atau urutan tindakan yang diperlukan untuk menjalankan suatu transaksi dengan baik dan benar secara tertib. Di dalam prosedur terdapat pembagian tugas yaitu yang mengerjakan, memeriksa, dan menyetujui. Penetapan prosedur diperlukan untuk melancarkan operasional dan mencegah kemungkinan penyalahgunaan wewenang (Marina et al., 2019). Prosedur transaksi menjadi syarat penting agar SIA dapat berjalan dengan baik, yaitu dengan mengubah sekelompok data menjadi informasi keuangan yang dibutuhkan bagi perusahaan. Karakteristik kualitatif laporan keuangan yang meliputi relevan (relevance), andal (reliability), dapat diperbandingkan (comparability), dan dapat di pahami (understandability) merupakan hasil dari implementasi SIA yang berkualitas, oleh karena itu erat kaitannya antara kualitas SIA dengan kinerja suatu perusahaan.

Salah satu yang dapat menciptakan daya saing adalah akuntabilitas, yang ditunjukkan melalui professionalism sehingga timbul kepercayaan masyarakat terhadap lembaga tersebut. Bentuk akuntabilitas lembaga adalah adanya koordinasi yang jelas antara pengelola lembaga, secara operasional akuntabilitas diwujudkan dalam bentuk: (1) pelaporan (reporting), (2) pelibatan (involving), dan (3) cepat tanggap (responding). Terdapat empat dimensi akuntabilitas, yaitu:

1. Akuntabilitas Kejujuran

2. Akuntabilitas Hukum

3. Akuntabilitas Proses

4. Akuntabilitas Program

5. Akuntabilitas Kebijakan

Dalam Permen KUKM Nomor 20 Tahun 2015 tentang penerapan pelaksanaan akuntabilitas, salah satu ruang lingkup penerapan akuntabilitas koperasi yaitu aspek akuntabilitas keuangan. Indikator penerapan akuntabilitas aspek keuangan antara lain yaitu ketersediaan sistem informasi, dan transparansi pengelolaan sistem akuntansi (Menteri Koperasi dan Usaha Kecil Menengah, 2015).

Penelitian ini merupakan penelitian kualitatif deskriptif, yaitu suatu metode penelitian yang berusaha menggambarkan dan menginterpretasikan objek apa adanya. Metode pengumpulan data melalui studi kepustakaan atau review dokumen, yaitu menggunakan data sekunder yang diperoleh dari website resmi institusi terkait, buku-buku, hasil penelitian terdahulu, serta bahan bacaan lain yang masih ada relevansi terhadap topik penelitian. Menurut Milles dan Huberman yang dikutip oleh Sugiyono dalam bukunya Memahami Penelitian Kualitatif, bahwa aktivitas dalam analisis data deskriptif melalui tiga cara reduksi data (data reduction), penyajian data (data display), dan penarikan kesimpulan atau verifikasi (conclusion drawing /verification) (Sugiyono, 2019).

Analisis penelitian dilakukan berdasarkan model penelitian pada gambar 1 .

\section{Sistem Informasi Akuntansi (SIA)}

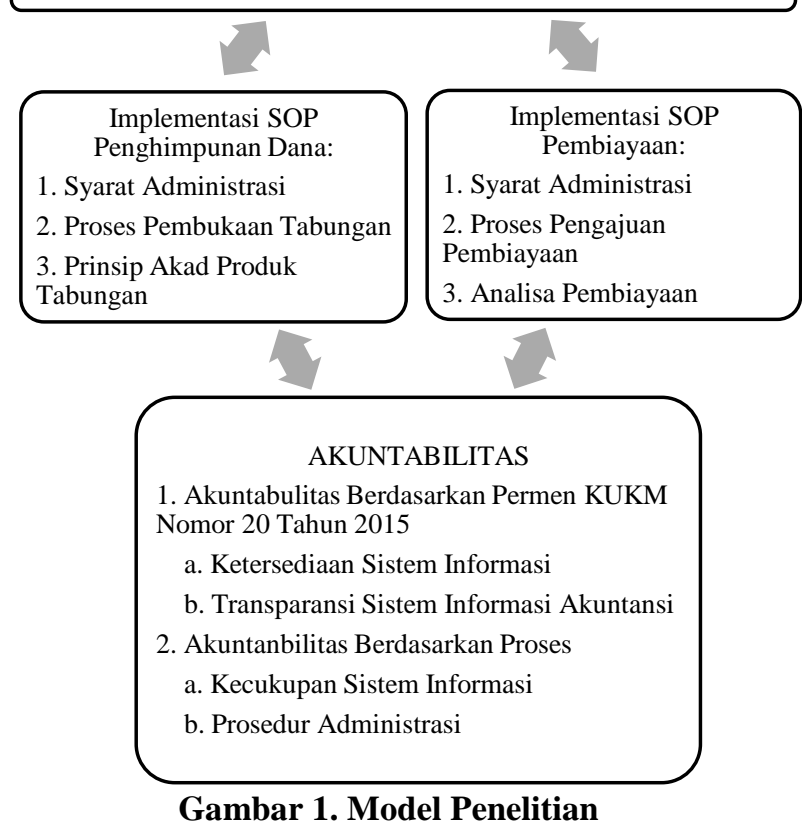

\section{PEMBAHASAN}

Pada umumnya bentuk badan hukum BMT adalah koperasi di mana AD/ART disahkan oleh menteri koperasi dan usaha kecil dan menengah, kemudian untuk memperoleh izin usaha, LKM wajib mengajukan permohonan kepada kantor Otoritas Jasa Keuangan (OJK) sesuai dengan ketentuan POJK Nomor 12/POJK.05/2014 tentang Pendirian Usaha dan Kelembagaan Lembaga Keuangan Mikro (Andri Soemitra, 2017). Struktur organisasi BMT terdiri dari badan pendiri, anggota BMT, badan pengawas, dan badan pengelola. Struktur Organisasi BMT dapat dilihat pada gambar 2 . 


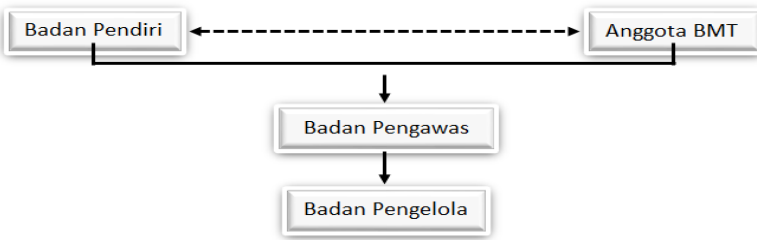

Gambar 2. Struktur Organisasi BMT

(Andri Soemitra, 2017)

Badan pengelola memiliki struktur organisasi tersendiri, badan pengelola merupakan sebuah badan yang mengelola BMT yang dipilih dari dan oleh badan pengawas. Badan pengelola terdiri dari Direktur atau ketua, kasir, pembukuan, dan pembiayaan. Struktur Badan Pengelola BMT Secara Sederhana dapat dilihat pada gambar 3 .

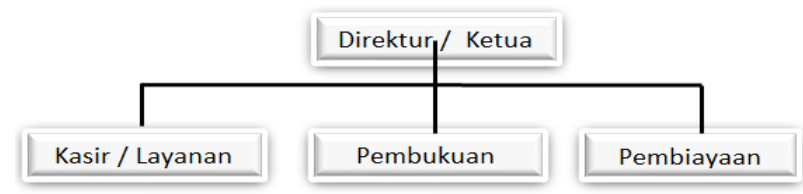

\section{Gambar 3. Struktur Badan Pengelola BMT Secara Sederhana}

(Andri Soemitra, 2017)

Dalam operasionalnya BMT menjalankan kegiatan keuangan dan non keuangan. Mekanisme operasional dimulai dari penggalangan dana (funding), kegiatan operasional, kemudian penyaluran dana (financing). Mekanisme operasional funding dan financing inilah yang di atur oleh SOP yang diterapkan. Tujuannya agar selain untuk efektifitas dan efisiensi kerja BMT, tetapi juga sebagai sistem pengawasan dalam mengontrol kinerja badan pengelola. Implementasi penerapan SOP funding dan financing adalah bentuk tanggungjawab BMT kepada pihak-pihak yang berkepentingan terhadap BMT. Mekanisme Operasional BMT dapat dilihat pada gambar 4 .

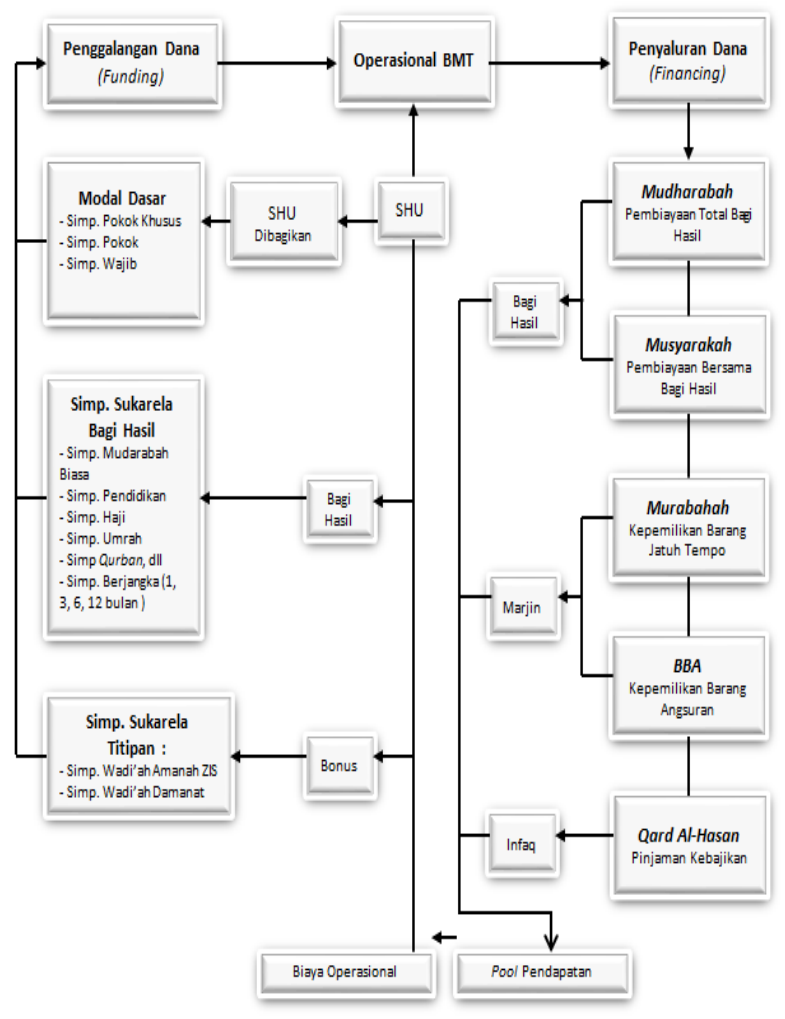

Gambar 4. Mekanisme Operasional BMT

(Amalia, 2016)

Berikut adalah jenis usaha BMT yang berkaitan dengan keuangan:

\section{Funding}

Terdiri dari modal awal berupa simpanan pokok khusus, simpanan pokok, dan simpanan wajib sebagai modal dasar BMT, lalu modal tersebut dikembangkan dalam bentuk simpanan sukarela berdasarkan akad wadiah dan mudharabah.

2. Financing

1) Pembiayaan Mudharabah dengan menggunakan mekanisme bagi hasil.

2) Pembiayaan Musyarakah dengan menggunakan mekanisme bagi hasil.

3) Piutang Murabahah merupakan kepemilikan suatu barang tertentu yang dibayar pada saat jatuh tempo, atau mekanisme jual beli.

4) Piutang Ba'i bi tsaman'ajil (BBA) merupakan kepemilikan suatu barang tertentu dengan mekanisme pembayaran cicilan atau mekanisme jual beli.

5) Piutang Qard al-hasan merupakan pinjaman tanpa ada tambahan pengembalian kecuali biaya administrasi. (Amalia, 2016)

\subsection{Deskripsi BMT Natijatul Umat}

BMT NJU adalah lembaga keuangan yang berlandaskan hukum koperasi serba usaha dengan menggunakan asas syari'ah dan telah beroperasi sejak 6 April 2007. Dengan memiliki izin badan hukum 
resmi dari Pemerintah Kabupaten Ponorogo (Dinas INDAKOP) No. 170/BH/XVI/121/2007, BMT NJU bertujuan untuk mengembangkan pemberdayaan ekonomi umat khususnya ekonomi kecil dan menengah. Struktur organisasi pada BMT NJU memiliki dua pengawasan yaitu pengawas manajemen dan pengawas syariah, yang harus dipatuhi oleh pengurus. Pengurus dipilih melalui Rapat Anggota Tahunan (RAT) dan dalam menjalankan operasional BMT dibantu oleh manager, accounting, personalia dan umum, serta bagian marketing. Masing-masing memiliki tugas dan fungsi tersendiri, terlihat dari standar operasional prosedur yang di miliki oleh BMT NJU. Struktur Organisasi BMT NJU dapat dilihat pada gambar 5 .

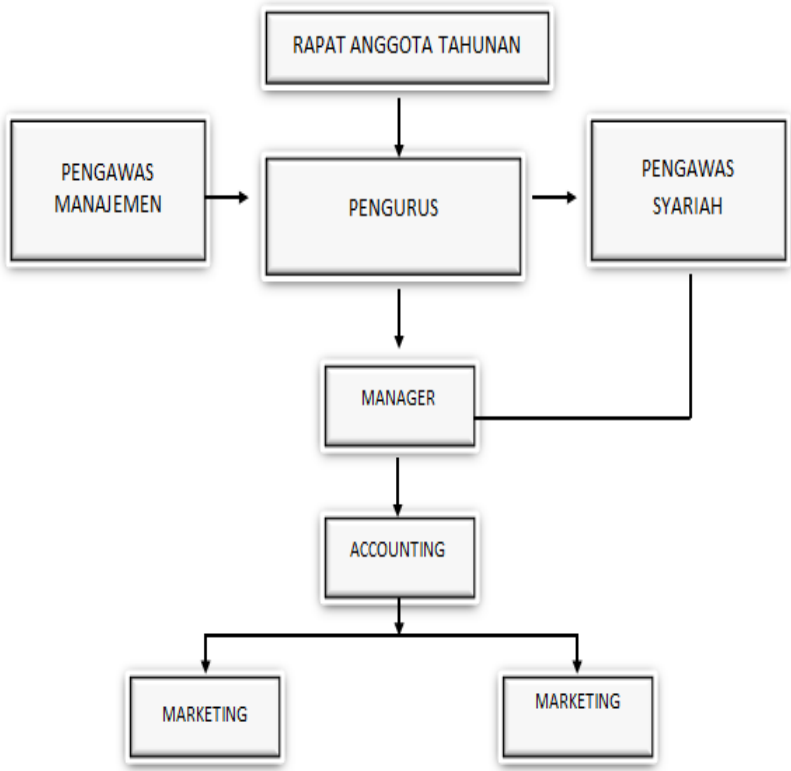

\section{Gambar 5. Struktur Organisasi BMT NJU}

(Website Resmi BMT NJU)

Kegiatan operasional BMT NJU meliputi: pemberdayaan ekonomi, permodalan, pemberdayaan manajemen, dan pemberdayaan sumber daya manusia (BMT Natijatul Umat, nd). Mekanisme operasional terbagi dua kegiatan seperti pada umumnya mekanisme operasional bank syariah yaitu funding dan financing. Funding terdiri dari skema titipan (wadiah) dan investasi (mudhrabah), sedangkan financing terdiri dari skema jual beli (murabahah), investasi (mudharabah dan musyarakah), sewa (ijarah), dan gadai (rahn). Selain itu juga terdapat kegiatan sosial dari BMT NJU yaitu skema qordul hasan. Pengelola BMT NJU sendiri terdiri manager, accounting, personalia dan umum, serta marketing. Marketing mempunyai peranan yang sangat penting dalam mengevaluasi penyaluran financing. Mekanisme Operasional BMT NJU dapat dilihat pada gambar 6 .

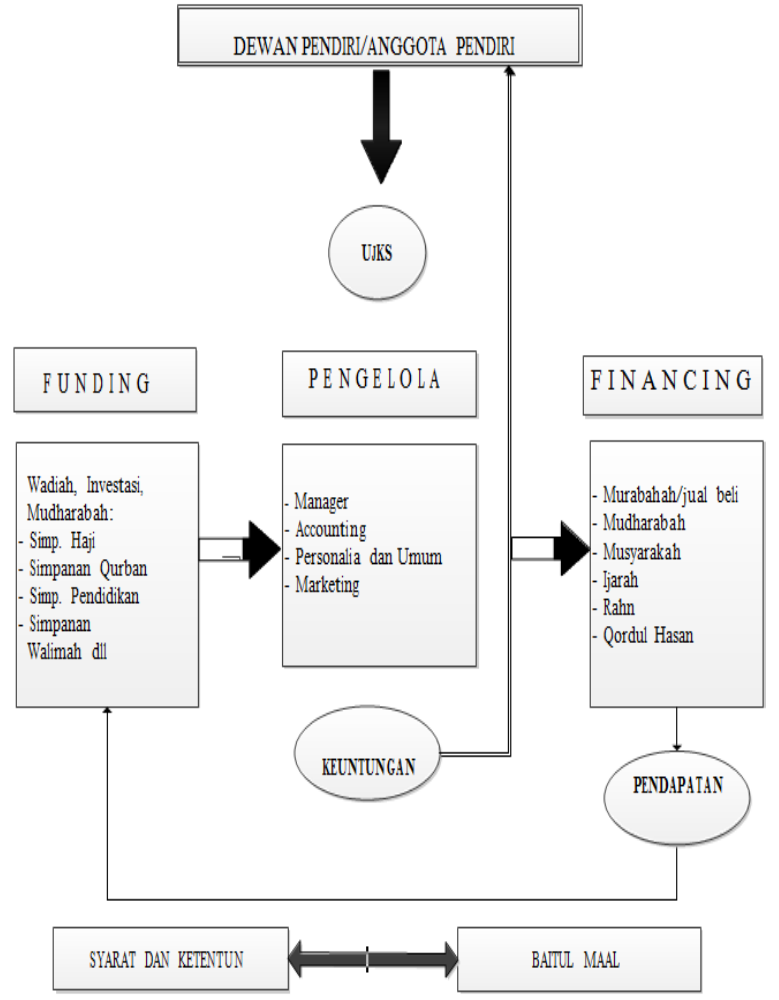

Gambar 6. Mekanisme Operasional BMT NJU (Website Resmi BMT NJU)

\subsection{Produk BMT Natijatul Umat}

Funding adalah kegiatan menghimpun dana dari anggota atau calon anggota yang berbentuk simpanan atau penyertaan modal guna penguatan modal. Berikut adalah produk funding dari BMT Natijatul Umat:

1. Simpanan Wadi'ah

2. Simpanan Pendidikan

3. Simpanan Walimah

4. Simpanan Wisata

5. Simpanan Qurban

6. Simpanan Mudharabah

7. Simpanan Masa Depan (Simapan)

Financing merupakan pembiayaan yang diberikan untuk keperluan produktif maupun konsumtif, dengan sistem bagi hasil, margin penjualan, atau fee. Berikut adalah produk financing dari BMT Natijatul Umat:

1. Pembiayaan Murabahah

2. Pembiayaan Mudharabah

3. Pembiayaan Musyarakah (syirkah atau syarikah atau serikat atau kongsi)

4. Pembiayaan Ijarah

5. Pembiayaan Rahn

6. Pembiayaan Qardhul Hasan

\subsection{Implementasi SOP Funding Dan Financing BMT Natijatul Umat}

Implementasi SOP penghimpunan dana BMT NJU atas tabungan wadiah, tabungan mudharabah, tabungan berjangka mudharabah, serta tabungan Qurban dan Aqiqah adalah sebagai berikut: 
1. Prosedur Persyaratan,

2. Proses Pembukaan Tabungan, dan

3. Prinsip Akad Produk Tabungan

Implementasi Standar operasional prosedur (SOP) penerapan pembiayaan pada BMT Natijatul Umat terbagi tiga, yaitu:

1. Persyaratan Administrasi,

2. Proses Pengajuan Pembiayaan, dan

3. Analis Pembiayaan

\subsection{Akuntabilitas Berdasarkan Permen KUKM Nomor 20 Tahun 2015}

Berdasarkan Permen KUKM Nomor 20 Tahun 2015 tentang penerapan pelaksanaan akuntabilitas, salah satu aspek ruang lingkup penerapan akuntabilitas koperasi yaitu aspek keuangan. Indikator penerapan akuntabilitas aspek keuangan antara lain yaitu ketersediaan sistem informasi dan transparansi pengelolaan sistem akuntansi. BMT NJU di katakan sudah memberikan ketersediaan sistem informasi akuntansi yaitu SOP funding (penghimpunan dana) dan SOP financing (pembiayaan). Sedangkan ketersediaan sistem informasi BMT NJU lainnya yang dapat mendukung akuntabilitas, yaitu:

1. Legalitas BMT NJU

BMT NJU merupakan lembaga keuangan yang sudah memiliki legalitas, yaitu merupakan koperasi serba usaha yang menggunakan pola syari'ah dan telah mendapat izin resmi dari Pemerintah Kabupaten Ponorogo (Dinas INDAKOP) dengan dikeluarkannya izin Badan Hukum No. 170/BH/XVI/121/2007.

2. Struktur organisasi

Struktur organisasi BMT NJU sudah memenuhi kriteria (gambar 5) jika dibandingkan dengan standar struktur organisasi untuk BMT pada umumnya yaitu pada gambar 2. Sudah terdapat pemisahan fungsi dan wewenang antara anggota BMT (Rapat Anggota Tahunan) dan pengurus (pendiri), pengawas (pengawas manajemen dan pengawas syariah), dan pengelola (manager, accounting, marketing, dll).

3. Kesesuaian produk yang dikeluarkan

Produk-produk penghimpunan dana dan pembiayaan pada BMT NJU sudah memenuhi kriteria, yaitu memenuhi akad transaksi syariah seperti wadiah, mudhrabah, musyarah, ijarah, rahn, dan Qardhul Hasan. Sedangkan untuk mekanisme operasional BMT NJU (gambar 6) jika dibandingkan dengan mekanisme operasional BMT pada umumnya seperti pada gambar 4 juga telah memenuhi kriteria, yaitu terdiri dari funding, pengelola (operasional), dan financing. Funding terdiri dari modal dasar (simpanan pokok) yaitu setoran minimal yang telah di tetapkan, simpanan sukarela berdasarkan bagi hasil dan sewa, kemudian simpanan sukarela titipan yaitu tabungan wadiah. Sedangkan financing yaitu pembiayaan dengan perolehan bagi hasil, margin, sewa, dan digunakan sebagai infak.

Bentuk transparansi pengelolaan yang dilakukan oleh BMT NJU, yaitu dengan cara mempublikasikan nya memalui website resmi BMT NJU. Ketersediaan sistem informasi dan transparansi pengelolaan SIA agar dapat menciptakan akuntabilitas yang dilakukan oleh BMT NJU, sesuai dengan bentuk transparansi dan akuntabilitas yang dilakukan oleh Organisasi Pengelola Zakat (OPZ) (Rahman, 2015). Berbeda dengan (Wartoyo and Meutia, 2016) yang menggunakan penerapan SIA pada Bank BNI syariah kantor cabang Cirebon untuk mengukur efektivitas pengendalian internal pembiayaan murabahah dengan menggunakan indikator Non Performing Financing (NPF). Hasilnya menunjukkan tingkat NPF masih dibawah standar Bank Indonesia (BI) yaitu 5\%, yang artinya penerapan SIA telah memadai dalam menunjang efektivitas pengendalian internal pembiayaan murabahah.

\subsection{Akuntabilitas Berdasarkan Proses}

Akuntabilitas proses terkait dengan pelaksanaan prosedur yang digunakan yaitu kecukupan sistem informasi dan prosedur administrasi. Kecukupan sistem informasi dalam menciptakan akuntabilitas sama dengan indikator berdasarkan Permen KUKM Nomor 20 Tahun 2015. Sedangkan prosedur akuntansi yaitu implementasi atas SOP funding (penghimpunan dana) dan SOP financing (pembiayaan) pada BMT Natijatul Umat.

Pada proses administrasi SOP funding (penghimpunan dana) di BMT NJU, terdapat tiga tahapan, yaitu pertama syarat administrasi, kedua proses pembukaan tabungan, dan ketiga prinsip akad produk tabungan. Pada tahap ketiga marketing menjelaskan mengenai saldo minimum dan setoran minimum, mekanisme akad transaksi (wadiah dan mudharabah) beserta nisbah bagi hasil sesuai dengan bentuk produk simpanan. Untuk produk tabungan berjangka mudhrabah, dapat di jadikan sebagai jaminan pembiayaan. Hasil investasi dapat di ambil secara tunai maupun di kredit kedalam tabungan nasabah. Dapat dilihat bahwa BMT NJU telah memberikan informasi yang memadai kepada nasabah terkait proses penghimpunan dana, dan juga dari segi proses administrasi tidak rumit jika di bandingkan dengan proses pada perbankan. Jadi dapat dikatakan bahwa penerapan SIA berupa SOP funding (penghimpunan dana) pada BMT NJU dapat menciptakan akuntabilitas.

Untuk proses administrasi SOP financing (pembiayaan) pada BMT NJU berbeda sesuai dengan jenis pembiayaan nya. Terdapat tiga tahapan prosedur untuk pembiayaan mudharabah dan musyarakah, yaitu pertama persyaratan administrasi, kedua proses pengajuan pembiayaan, dan ketiga analis pembiayaan. Hal ini sama dengan tahapan prosedur pembiayaan murabahah di BMT UMY, yaitu pertama pemohon telah memenuhi syarat-syarat sebagai pemohon, kedua 
bagian pembiayaan mengumpulkan beberapa berkas yang telah diajukan si pemohon guna dilakukan penanganan oleh tim surveyor, dan ketiga tim surveyor melakukan analis kelapangan (Hanjani and Ari Haryati, 2018). Di BMT NJU sendiri untuk tahapan prosedur pembiayaan murabahah, hanya melalui dua tahap yaitu persyaratan administrasi dan proses pengajuan pembiayaan. Prosedur pembiayaan musyarakah pada BMT Batik Mataram juga sesuai dengan yang di lakukan oleh BMT NJU, yaitu terdapat syarat administrasi, proses pengajuan pembiayaan, dan analis pembiayaan (Vitasari, 2018) .

Proses analis pembiayaan terhadap nasabah di BMT NJU, dilakukan tidak hanya oleh account officer atau marketing manager (analis pembiayaan). Melainkan melalui beberapa fungsi lain, yaitu manager, surveyor, dan juga hasil rapat dari pengelola BMT yang memutuskan disetujui atau tidaknya suatu permohonan pembiayaan. Sehingga timbulnya penilaian yang terlalu subjektif terhadap nasabah dapat dihindari, karena terdapat tahapan proses analisis yang saling melengkapi. Berbeda dengan yang terjadi pada penerapan SOP pembiayaan mudharabah tanpa agunan di KSPPS Amanah Usaha Mulia (AULIA) Magelang yang dinilai kurang, sehingga mengakibatkan terjadinya penilaian yang terlalu subjektif dan over estimate atas kelayakan usaha yang dilakukan oleh account officer (Nuraeni, 2019).

\section{KESIMPULAN}

Peran BMT Natijatul Umat (BMT NJU) yang berlokasi di Kecamatan Babadan Ponorogo, terutama di masa pandemi Covid-19 ini sangat penting. Kepercayaan masyarakat terhadap kinerja BMT berkaitan erat dengan fungsinya, terutama dalam meningkatkan dan menguatkan pengelolaan ZISWafnya kepada anggota atau nasabah yang terdampak pandemi Covid-19. Kinerja BMT NJU dilihat melalui penerapan Sistem Informasi Akuntansi (SIA) melalui implementasi prosedur funding (penghimpunan dana) dan implementasi prosedur financing (pembiayaan).

Berdasarkan Permen KUKM Nomor 20 Tahun 2015 dan akuntabilitas proses, hasilnya bahwa BMT NJU memenuhi kriteria dalam menciptakan akuntabilitas. Ini terlihat dari adanya ketersediaan, transparansi, dan pelaksanaan sistem informasi akuntansi yaitu SOP funding (penghimpunan dana) dan SOP financing (pembiayaan) yang telah dilaksanakan dengan baik dan memadai. BMT NJU telah memberikan informasi yang lengkap kepada nasabah, dan juga efisien dan efektif dari segi administrasi jika di bandingkan dengan proses perbankan pada umumnya. Serta telah menerapkan prosedur yang sesuai bagi BMT pada umumnya, bahkan lebih baik karena prosedur BMT NJU dapat mengantisipasi terjadinya proses analisis penilaian yang terlalu subjektif.

\section{SARAN}

Penerapan SIA dalam menciptakan akuntabilitas pada penelitian ini baru diukur melalui implementasi prosedur funding dan financing yaitu aspek akuntabilitas proses, dan aspek keuangan yaitu ketersediaan sistem informasi dan transparansi. Akuntabilitas sendiri dapat tercipta dari aspek akuntabilitas lain, yaitu akuntabilitas kejujuran dan akuntabilitas hukum, akuntabilitas program, dan akuntabilitas kebijakan. Aspek akuntabilitas lain tersebut dapat dijadikan sebagai penelitian selanjutnya, dalam mewujudkan lembaga yang akun tabel yang beroperasi secara efisien dan efektif.

\section{DAFTAR PUSTAKA}

Alrabei, D.A.M.A., 2017. The Impact of Accounting Information Systems on Turkish Banks: An Empirical Study. Eur. Sci. J. 10, 184-198.

Amalia, E., 2016. Lembaga Keuangan Mikro Syariah. Gramata Publishing.

Andri Soemitra, 2017. Bank \& Lembaga Keuangan Syariah, Kedua. ed. Kencana Prenada Media Group.

BMT Natijatul Umat, 2020. BMT Natijatul Umat [WWW Document]. Website BMT Natijatul Umat. URL https://bmtnatijatulumat.wordpress.com/dstruktur-organisasi/ (accessed 9.20.20).

Hanjani, A., Ari Haryati, D., 2018. Mekanisme Pembiayaan Murabahah Pada Nasabah di Baitul Maal Wa Tamwil Universitas Muhammadiyah Yogyakarta. Jati J. Akunt. Terap. Indones. 1, 4651. https://doi.org/10.18196/jati.010105

Khoiriyah, N., 2017. Analisis Tingkat Kesehatan Pada BMT Natijatul Umat Babadan Ponorogo Periode 2012-2015 Dengan Metode RGEC. Skripsi Stain Ponorogo.

Marina, A., Wahjono, S.I., Sya'ban, M., Suarni, A., 2019. Sistem Informasi Akuntansi, 1st ed. Raja Grafindo Persada.

Mubarok, A., Utami, Y., 2016. Penerapan Sistem Informasi Akuntansi Pada Lembaga Keuangan Mikro Syariah "BMT" Di Tegal. J. Kewirausahaan dan Usaha Kecil Menengah 1, 91-98.

Noor, R.R. Al, 2018. Analisis Penerapan Prinsip Akuntabilitas, Partisipasi, dan Transparansi dalam Implementasi Tata Kelola Koperasi Jasa Keuangan Syariah Baitul Maal Wattamwil Binaan Dinas Koperasi dan UKM Kota Padang. E-Journal UNP.

Nuraeni, A.F., 2019. Standar Operasional Prosedur (SOP) Pembiayaan Mudharabah Tanpa Agunan Di KSPPS Amanah Usaha Mulia (Aulia) Magelang. Skripsi.

Rahman, T., 2015. Akuntansi Zakat, Infak dan Sedekah (PSAK 109): Upaya Peningkatan Transparansi 
dan Akuntabilitas Organisasi Pengelola Zakat (OPZ). Muqtasid J. Ekon. dan Perbank. Syariah 6 ,

141. https://doi.org/10.18326/muqtasid.v6i1.141-164

Sugiyono, 2019. Metode Penelitian Kuantitatif, Kualitatif, dan R\&D, 2nd ed. Alfabeta.

Sulistiani, D., 2019. Peningkatan Akuntabilitas Publik Melalui Sistem Informasi Akuntansi pada Pondok Pesantren Salafiyah. Akuntabilitas 12, 237-248. https://doi.org/10.15408/akt.v12i2.9662

Usnan, 2019. Penerapan Prinsip Akuntabilitas Dan Transparansi Pada Pengelolaan Bmt Di Kota Surakarta (Studi pada BMT Al-Madinah). Jrka 5, 83-95.

Wartoyo, Meutia, N.G., 2016. Analisis Penerapan Sistem Informasi Akuntansi Dalam Menunjang
Efektivitas Pengendalian Internal Pembiayaan Murabahah Di Bank Syariah. J. Ekon. Islam 4, 345-376.

Wijayanti, V., 2010. Sistem Akuntansi Pembiayaan Pada BMT Bondho Tumoto Gunungpati Semarang. Skripsi.

Vitasari, D., 2018. Prosedur Pembiayaan Musyarakah Pada Bmt Batik Mataram (Laporan Magang).

\section{UCAPAN TERIMA KASIH}

Terima kasih yang sebesar-besarnya kami ucapkan kepada pihak-pihak yang telah mendukung dan membantu penelitian ini yaitu Universitas Pembangunan Nasional (UPN) Veteran Jakarta. 